Voice of the Living Light 



\section{Voice of the Living Light}

Hildegard of Bingen

and Her World

Edited by

Barbara Newman

UNIVERSITY OF CALIFORNIA PRESS

Berkeley · Los Angeles · London 
University of California Press

Berkeley and Los Angeles, California

University of California Press, Ltd.

London, England

(C) 1998 by

The Regents of the University of California

Library of Congress Cataloging-in-Publication Data

Voice of the living light : Hildegard of Bingen and her world / edited by Barbara Newman.

p. cm.

Includes bibliographical references and index.

ISBN 0-520-20826-9 (alk. paper)

ISBN 0-520-21758-6 (pbk. : alk. paper)

I. Hildegard, Saint, rog8-ı I79. 2. Germany-Intellectual life.

I. Newman, Barbara, 1953- .

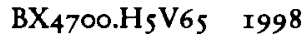

$282^{\prime} .092-\mathrm{dc2} I$

[b]

98-14149

CIP

Printed in the United States of America

987654321

The paper used in this publication meets the minimum requirements of American National Standard for Information Sciences-Permanence of Paper for Printed Library Materials, ANSI Z39.48-I984. 